\title{
Pre-Weaning Growth Performance of Piglets at Smallholder Farms in Gauteng Province
}

\author{
Matshidiso B. Matabane ${ }^{1}$, Khathutshelo A. Nephawe ${ }^{2}$, Ronald S. Thomas ${ }^{3}$, Ayanda Maqhashu ${ }^{3}$, \\ Fhulufhelo V. Ramukhithi ${ }^{3}$, Thivhilaheli R. Netshirovha ${ }^{3}$, Jones W. Ng'ambi ${ }^{1}$, Mammikele Tsatsimpe ${ }^{4}$ \\ \& Tshimangadzo L. Nedambale ${ }^{2,5}$ \\ ${ }^{1}$ Department of Agricultural Economics and Animal Production, University of Limpopo, Sovenga, South Africa \\ ${ }^{2}$ Department of Animal Science, Tshwane University of Technology, Pretoria, South Africa \\ ${ }^{3}$ Animal Production Institute, Agricultural Research Council, Irene, South Africa \\ ${ }^{4}$ Research and Technology Development Services, Gauteng Department of Agriculture and Rural Development, \\ Johannesburg, South Africa \\ ${ }^{5}$ Department of Animal, Wildlife and Grassland Sciences, University of the Free State, Bloemfontein, South \\ Africa \\ Correspondence: Tshimangadzo L. Nedambale, Department of Animal Science, Tshwane University of \\ Technology, Pretoria, South Africa. Tel: 27-12-382-4467. E-mail: nedambaletl@tut.ac.za
}

Received: Agust 28, 2017

doi:10.5539/jas.v10n4p18
Accepted: January 29, $2018 \quad$ Online Published: March 15, 2018

URL: https://doi.org/10.5539/jas.v10n4p18

\begin{abstract}
The objective of the study was to determine pre-weaning performance of piglets born following artificial insemination (AI) at smallholder farms of Gauteng province. Data from 496 piglets originating from 73 multiparous crossbred sows were used in the study. Litter size, number of piglets born alive, number of piglets weaned, birth and weaning weights were recorded. Data was analysed using the Proc Univariate procedure of SAS. The average litter size was 11.8 . The average birth weight and weaning weights were 1.9 and $6.2 \mathrm{~kg}$, respectively. No significant differences were found between male and female piglets for all the growth performance characteristics. Piglets born during winter had a significantly higher $(\mathrm{P}<0.05)$ birth and weaning weight as compared to autumn and summer months. Season had a significant effect on birth and weaning weight $(\mathrm{P}<0.01)$. However, sex of piglets had no significant effect on all the characteristics recorded $(\mathrm{P}>0.05)$. The interaction between sex and season was only confirmed on the total number of weaned piglets $(\mathrm{P}<0.01)$. A highly significant positive correlation was found between litter size and number of piglets born alive $(\mathrm{r}=0.86)$ and total number of piglets weaned $(\mathrm{r}=0.50)$. A highly significant correlation was found between total number of piglets born alive and total number of piglets weaned $(\mathrm{r}=0.55)$. In conclusion, season of birth had the greatest impact on birth and weaning weight, with the highest birth and weaning weights recorded during winter season. However, sex did not affect the pre-weaning performance of piglets.
\end{abstract}

Keywords: birth weight, gender, litter size, pigs, weaning weight

\section{Introduction}

The South African pig industry is small in terms of the total South African agricultural sector contributing around $2.05 \%$ to the primary agricultural sector (DAFF, 2015). Furthermore, South Africa contributes about $0.2 \%$ of the world pig population (Muchenje \& Ndou, 2010). According to Phiri et al. (2003), South Africa has the highest pig populations in southern Africa and $25 \%$ are free ranging in rural-poor areas. According to Harvey et al. (2014), smallholder farmers normally depend on farming for their livelihoods with inadequate skills and resources, therefore any decline in productivity may have a significant impact on their food security, nutrition and income. Pigs are of high economic importance, especially among the resource-poor as they contribute towards human nutrition, food security, poverty alleviation, enhanced livelihood and creation of employment for the rural community (Antwi \& Seahlodi, 2011). However, according to literature, reproductive performance of pigs in smallholder systems is generally unsatisfactory (Phengsavanh \& Ogle, 2010). This may be attributed to limited access to superior germplasm. Therefore, advances in reproductive technologies such as artificial 
insemination (AI) offers unique opportunities for livestock improvement for smallholder pig farmers (Rege et al., 2011).

One of the main reasons for introducing the improved pig breeds through AI is to facilitate the dissemination and propagation of superior germplasm (Okwun, Igboeli, Ford, Lunstra, \& Johnson, 1996). Furthermore, sow productivity is dependent on the sow's ability to produce piglets that survive from birth to weaning (Fix et al., 2010). Noteworthy, the productive output of pigs depends on several factors. There are different factors that have been shown to be related such as nutrition, season of birth, diseases, stress, dam's age and parity, social status, levels of different hormones, type and timing of the insemination, oestrus synchronisation, environment, population demography, etc. (Chandler, Steinholt-Chenevert, Adkinson, \& Moser, 1998). However, seasonal infertility remains a major problem.

Seasonal infertility is one of the most vital environmental factors that influences the reproductive performance of pigs (Janse van Rensberg \& Spender, 2014). It has been established that it has a direct influence on litter size and piglet survival following birth (Tummaruk, Tantasuparuk, Techakumphu, \& Kunavongkrit 2010). Additionally, it may affect results in the rearing of piglets due to heat stress and feed intake during lactation. Within the season, temperature variation and photoperiodic reaction are considered the main causes influencing fertility (Knecht, Srodon, \& Duzinski, 2015), although the resistance of individuals is dependent on the breed (Wysokinska \& Kondracki, 2013). The sex of the offspring also influences the growth performance of piglets (Peaker \& Taylor, 1996). It also plays an integral role in the growth rate of the developing foetus. Alfonso (2005) reported that at birth male piglets tended to be heavier than female piglets. This may be due to hormonal differences between males and females and subsequent effects of foetal growth. Therefore, the objective of the study was to determine the effect of sex and season on pre-weaning performance of piglets following AI at smallholder farms in Gauteng Province.

\section{Materials and Methods}

\subsection{Location and Experimental Area}

The study was conducted at nine smallholder farms of Gauteng Province based on the availability of breeding sows between 2014 and 2015. December to February were grouped as summer months with temperature ranging from 16 to $29^{\circ} \mathrm{C}$, March to May were grouped as autumn months with temperature ranging from 11 to $23^{\circ} \mathrm{C}$ and June to August were grouped as winter months with temperatures ranging from 5 to $20{ }^{\circ} \mathrm{C}$ with an average rainfall of $1454 \mathrm{~m}$. All procedures performed in the study involving humans and animals were in accordance with the ethical standards of the ARC (ARC Reference: APIEC15-046).

\subsection{Experimental Design}

A factorial design was used in the present study. Sex (males and females) and season of birth (summer, autumn and winter) were the main factors.

\subsection{Animals}

A total of 73 multiparous sows were synchronised by administering $400 \mathrm{IU}$ of Equine Chorionic Gonadotropin and $200 \mathrm{IU}$ of Human Chorionic Gonadotropin intramuscular in the neck. Each sow was checked for heat twice a day. Sows were further stimulated by back pressure and inseminated twice, 12 and 24 hours after standing heat. Each AI dose consisted of $80 \mathrm{~mL}$ of extended semen containing $3 \times 10^{9}$ spermatozoa. Pregnancy diagnosis was done 42 days following artificial insemination using ultrasound scanner. Conception rate, farrowing rate, litter size and total born alive were recorded. The production performance of 73 crossbred sows and its litter were collected for a period of two years from the records maintained at smallholder pig farms in Gauteng Province. Litter size, number of piglets born alive, number of piglets weaned, birth and weaning weights were recorded.

\subsection{Statistical Analysis}

All of the statistical analyses were performed using SAS software Version 9.2. Data was analyzed using the PROC UNIVARIATE procedure. Pearson correlation coefficients was used to determine the relationship between litter size, total number of piglets born alive, total number of piglets weaned, birth and weaning weight. Data was presented as mean \pm standard deviation. Differences were considered significant at $\mathrm{P}<0.05$.

\section{Results and Discussion}

Descriptive productivity of piglets following AI at smallholder farms is indicated in Table 1. The average litter size was 11.8 based on the sample of 496 piglets. Furthermore, the number of piglets born alive was 10.2 and 9.5 for number piglets weaned. The average birth weight was $1.9 \mathrm{~kg}$ ranging from 0.8 to $2.4 \mathrm{~kg}$. Moreover, the average weaning weight was 6.2 ranging from 2.9 to $12.2 \mathrm{~kg}$. Sharma, Dubey, and Singh (1990) reported that a 
weaning weight of $7.4 \mathrm{~kg}$ in Large White Yorkshire (LWY) pigs and Cauveri, Sivakumar, \& Devendran, (2009) reported weaning weight of $6.8 \mathrm{~kg}$ at 42 days of age in $75 \% \mathrm{LWY}$ crossbred pigs which were lower compared the results in the present study $(6.2 \mathrm{~kg})$.

Table 1. Descriptive growth performance of piglets following AI at smallholder farms

\begin{tabular}{llll}
\hline Characteristics & Average & Minimum & Maximum \\
\hline Litter size & $11.8 \pm 3.5$ & 4 & 20 \\
Total number of live born piglets & $10.2 \pm 3.1$ & 3 & 18 \\
Total number of weaned piglets & $9.5 \pm 3.1$ & 0 & 15 \\
Birth weight $(\mathrm{kg})$ & $1.9 \pm 0.7$ & 0.8 & 2.4 \\
Weaning weight $(\mathrm{kg})$ & $6.2 \pm 2.2$ & 2.9 & 12.2 \\
\hline
\end{tabular}

Detailed results of the pre-weaning performance following AI at smallholder farms is indicated in Table 2. No significant differences $(\mathrm{P}>0.05)$ were found between males and females for pre-weaning performance. Similarly, Cauveri et al. (2009) reported that sex had no significant impact on birth weight. Jaishankar et al. (2015) further indicated that the average birth weight was higher in male piglets $(1.2 \mathrm{~kg})$ compared to female piglets $(1.1 \mathrm{~kg})$, which is slightly lower from the results in the present study $(1.9 \mathrm{~kg})$. However, Darko and Buadu (1998) indicated that females tended to be heavier at birth than males. Contrary to these findings, Poore and Fowden (2004) found that males have a higher weaning weight compared to females. Similarly, Milligan, Fraser, and Kramer (2001) reported that on average, males were heavier at birth than females. In general, birth weight, preand post-weaning growth performance of piglets decreased with an increasing litter size.

Table 2. Growth performance following AI at smallholder farms

\begin{tabular}{|c|c|c|c|c|c|c|c|c|c|}
\hline \multirow{2}{*}{ Variables } & \multicolumn{3}{|c|}{ Males } & \multicolumn{3}{|c|}{ Females } & \multicolumn{3}{|c|}{ P-value } \\
\hline & Summer & Autumn & Winter & Summer & Autumn & Winter & Sex & Season & Sex $x$ season \\
\hline Litter size & $10.3 \pm 6.7$ & $10.5 \pm 1.2$ & $11.7 \pm 3.0$ & $11.8 \pm 2.4$ & $13.5 \pm 4.9$ & $9.5 \pm 3.5$ & 0.6623 & 0.5917 & 0.1218 \\
\hline Total number of piglets born alive & $10.3 \pm 6.7$ & $8.0 \pm 0.2$ & $10.2 \pm 3.2$ & $10.6 \pm 2.3$ & $13.5 \pm 0.7$ & $9.0 \pm 0.2$ & 0.7592 & 0.8059 & 0.3023 \\
\hline Total number of piglets weaned & $9.3 \pm 0.6^{\mathrm{ab}}$ & $8.0 \pm 0.2^{b}$ & $9.8 \pm 2.7^{\mathrm{ab}}$ & $9.8 \pm 1.3^{\mathrm{ab}}$ & $12.0 \pm 1.4^{\mathrm{a}}$ & $6.2 \pm 1.2^{\mathrm{c}}$ & 0.7049 & 0.3547 & $<0.01$ \\
\hline Birth weight (kg) & $1.8 \pm 0.6^{\mathrm{c}}$ & $1.9 \pm 0.8^{c}$ & $2.4 \pm 0.4^{\mathrm{a}}$ & $1.6 \pm 0.5^{\mathrm{c}}$ & $2.0 \pm 0.9^{\mathrm{bc}}$ & $2.2 \pm 0.4^{\mathrm{ab}}$ & 0.2450 & $<0.01$ & 0.3194 \\
\hline Weaning weight $(\mathrm{kg})$ & $5.3 \pm 1.2^{b}$ & $5.5 \pm 0.4^{b}$ & $8.1 \pm 0.9^{\mathrm{a}}$ & $5.0 \pm 1.2^{b}$ & $5.0 \pm 0.1^{\mathrm{b}}$ & $8.0 \pm 1.3^{\mathrm{a}}$ & 0.2756 & $<0.01$ & 0.6694 \\
\hline
\end{tabular}

Note. ${ }^{\text {abc }}$ Means with different superscripts in the same row differ significantly $(P<0.05)$.

Season had no significant effect $(\mathrm{P}>0.05)$ on the litter size, total piglets born alive at birth and total number of piglets at weaning. However, piglets born in winter had a significantly higher birth and weaning weight as compared to autumn and summer seasons. It is evident that farrowing season plays a significant role in growth performance indirectly through its influence on the dam's nutrition and hence amount of milk available to the unweaned offspring. In the present study, birth and weaning weight were the lowest during autumn and summer seasons. This may be due to their reduced ability to maintain their body temperature and low colostrum and milk intake (Herpin et al., 1996). Furthermore, literature relating to the association between low birth weight and lower survival rate or a lower growth performance is abundant (Fix et al., 2010; Baxter et al., 2009; Quiniou, Dagorn, \& Gaudre, 2002). In the present study, sows produced piglets with lower birth weights during summer months. Similarly, it was previously reported that sows tended to produce smaller litters with lower birth weights during hot or warm seasons (Tummaruk \& Khatiworavage, 2011; Quiniou et al., 2002). Low weaning weights observed during summer may be attributed to the microclimate conditions affecting lactation. Pigs tend to be sensitive to high ambient temperature because their inability to sweat. Hence, it is of utmost importance to observe the body condition of sows especially during late pregnancy. Moreover, physiological changes that take place during farrowing and lactation may be affected by change in diets, postnatal stress and microclimatic factors (Quesnel et al., 2009). Additional heat stress during summer months contributes greatly to changes in the composition of milk, less milk secretion or decreased food consumption by piglets. Sex had no effect on all the evaluated characteristics recorded $(\mathrm{P}>0.05)$. The interaction between the sex and season were only confirmed on the total number of weaned piglets $(\mathrm{P}<0.0001)$. 
Pearson correlation coefficients between litter size, total number of piglets born alive, total number of piglets weaned, birth and weaning weight are shown in Table 3. A highly significant positive correlation was found between litter size and number born alive $(\mathrm{r}=0.86, \mathrm{P}<0.01)$ and total number of piglets weaned $(\mathrm{r}=0.50, \mathrm{P}<$ $0.05)$. However, a relatively low correlation $(\mathrm{P}>0.05)$ was found between litter size and birth $(\mathrm{r}=0.34)$ and weaning weight $(\mathrm{r}=0.22)$. In contrast, litter size is negatively correlated to the average birth weight and weaning weight (Raseel, Kotresh, \& Sunanda, 2016). There was also a significant correlation between total number of piglets born alive and total number of piglets weaned $(\mathrm{r}=0.55, \mathrm{P}<0.05)$. A low negative correlation was observed between the total number of piglets weaned and birth weight $(\mathrm{r}=-0.07)$ and weaning weight $(\mathrm{r}=-0.20)$, although insignificant. Furthermore, there was a highly significant positive correlation between birth weight and weaning weight $(r=0.5 ; \mathrm{P}<0.01)$. These findings are in agreement with studies from Raseel et al. (2016). This positive correlation of birth weight and weaning weight may indicate that as the birth weight increases the weaning weight also increases.

Table 3. Pearson correlation coefficients between litter size, total number of piglets born alive, total number of piglets weaned, birth and weaning weight

\begin{tabular}{llllll}
\hline Characteristics & Litter size & $\begin{array}{l}\text { Total number of } \\
\text { live born piglets }\end{array}$ & $\begin{array}{l}\text { Total number } \\
\text { of weaned piglets }\end{array}$ & $\begin{array}{l}\text { Birth weight } \\
(\mathrm{kg})\end{array}$ & $\begin{array}{l}\text { Weaning weight } \\
(\mathrm{kg})\end{array}$ \\
\hline Litter size & 1.00 & & & & \\
Total number of live born piglets & $0.86 * *$ & 1.00 & & & \\
Total number of weaned piglets & $0.50 *$ & $0.55 *$ & 1.00 & 1.00 & 1.00 \\
Birth weight $(\mathrm{kg})$ & 0.34 & 0.28 & -0.07 & $0.50 * *$ & -0.20 \\
Weaning weight $(\mathrm{kg})$ & 0.23 & 0.11 & & & \\
\hline
\end{tabular}

Note. ${ }^{*} \mathrm{P}<0.05 ;{ }^{* *} \mathrm{P}<0.01$.

\section{Conclusion}

In conclusion, season of birth had the greatest impact on birth and weaning weight, with the highest birth and weaning weights recorded during winter season. Moreover, the interaction between the sex and season was only confirmed on the total number of weaned piglets. However, sex did not affect the pre-weaning performance of piglets. Further research is recommended to determine the impact of season, sex, management, parity and nutrition on pre and post weaning productivity at smallholder farms.

\section{Acknowledgements}

The Agricultural Research Council and Gauteng Department of Agriculture and Rural Development funded the study.

\section{References}

Alfonso, L. (2005). Sex ratio of offspring in pigs: Farm variability and relationship with litter size and piglet birth weight. Spanish Journal of Agricultural Research, 3(3), 287-295. https://doi.org/10.5424/sjar/2005 033-151

Antwi, M., \& Seahlodi, P. (2011). Marketing constraints facing emerging small-scale pig farmers in Gauteng Province, South Africa. Journal of Human Ecology, 36, 37-42. https://doi.org/10.1080/09709274.2011. 11906415

Baxter, E. M., Jarvis, S., Sherwood, L., Robson, S. K., Ormandy, E., Farish, M., Edwards, S. A. (2009). Indicators of piglet survival in an outdoor farrowing system. Livestock Science, 124, 266-276. https://doi.org/10.1016/j.livsci.2009.02.008

Cauveri, D., Sivakumar, T., \& Devendran, P. (2009). Preweaning body weights in Large White Yorkshire crosses. Indian Journal of Animal Research, 43(2), 130-132.

Chandler, J. E., Steinholt-Chenevert, H. C., Adkinson, R. W., \& Moser, E. B. (1998). Sex ratio by polymerase chain reaction, calving and farrowing variation between ejaculates within sire evaluated records. Journal of Dairy Science, 81, 1855-1867. https://doi.org/10.3168/jds.S0022-0302 (98)75756-X

Darko, K., \& Buadu, M. K. (1998). The performance of a herd of Ashanti Dwarf pigs in the Forest Zone of Ghana. Proceedings of the 24th Ghana Animal Science Association Symposium (p. 88). Faculty of Agriculture, University of Science and Technology, Kumasi. 
Department of Agriculture, Forestry and Fisheries (DAFF). (2015). A profile of the South African pork market value chain. Department of Agriculture, Forestry and Fisheries. http://www.nda.agric.za/doaDev/sideMenu/ Marketing/Annual\%20Publications/Commodity\%20Profiles/Livestock/Pork\%20market\%20value\%20chain \%20profile\%202015.pdf

Fix, J. S., Cassady, J. P., Herring, W. O., Holl, J. W., Culbertson, M. S., \& See M. T. (2010). Effect of piglet birth weight on body weight, growth, backfat, and longissimus muscle area of commercial market swine. Livestock Science, 127, 51-59. https://doi.org/10.1016/j.livsci.2009.08.007

Harvey, C. A., Rakotobe, Z. L., Rao, N. S., Dave, R., Razafimahatratra, H., Rabarijohn, R. H., ... MacKinnon, J. L. (2014). Extreme vulnerability of smallholder farmers to agricultural risks and climate change in Madagascar. Philosophical Transactions of the Royal Society B: Biological Sciences, 369, 1-12. https://doi.org/10.1098/rstb.2013.0089

Herpin, P., Damon, M., \& Le Dividich, J. (2002). Development of thermoregulation and neonatal survival in pigs. Livestock Production Science, 78, 25-45. https://doi.org/10.1016/S0301-6226 (02)00183-5

Herpin, P., Le Dividich, J., Hulin, J. C., Fillaut, M., de Marco, F., \& Berlin, R. (1996). Effects of the level of asphyxia during delivery on viability at birth and early postnatal vitality of newborn pigs. Journal of Animal Science, 74, 2067-2075. https://doi.org/10.2527/1996.7492067x

Jaishankar, S., Murugan, M., \& Gopi, H. (2015). Comparative pre-weaning performance of 75\% Large White Yorkshire crossbred pigs of fifth and sixth filial generation. International Journal of Science, Environment and Technology, 4(4), 1236-1239.

Janse van Rensburg, L., \& Spencer, B. T. (2014). The influence of environmental temperatures on farrowing rates and litter sizes in South African pig breeding units. Onderstepoort Journal of Veterinary Research, 81(1), 1-7. https://dx.doi.org/10.4102/ojvr.v81i1.824

Knecht, D., Srodon, S., \& Duzinski, K. (2015). The impact of season, parity and breed on selected reproductive performance parameters of sows. Archives Animal Breeding, 58, 49-56. https://doi.org/10.5194/aab-5849-2015

Milligan, B. N., Fraser, D., \& Kramer, D. L. (2001). Birth weight variation in the domestic pig: Effects on offspring survival, weight gain and suckling behaviour. Applied Animal Behaviour Science, 73, $179-191$. https://doi.org/10.1016/S0168-1591 (01)00136-8

Muchenje, V., \& Ndou, S. P. (2010). How pig pre-slaughter welfare affects pork quality and the pig industry. Porcus (August/September, pp. 38-39).

Okwun, O. E., Igboeli, G., Ford, J. J., Lunstra D. D., \& Johnson, L. (1996). Number and Function of sertoli cell, number and yield of Spermatogonia and daily sperm production in three breeds of boars. Journal of Reproduction and Fertility, 107, 137-149. https://doi.org/10.1530/jrf.0.1070137

Peaker, M., \& Taylor, E. (1996). Sex ratio and litter size in guinea pig. Journal of Reproduction and Fertility, 103, 63-67. https://doi.org/10.1530/jrf.0.1080063

Phengsavanh, P., \& Ogle, B. (2010). Feeding and performance of pigs in smallholder production systems in Northern Lao PDR. Tropical Animal Health Production, 42(8), 1627-1633. https://doi.org/10.1007/s11250010-9612-4

Phiri, I. K., Ngowi, H., Afonso, S., Matenga, E., Boa, M., Mukaratiwa, S., Willingham III, A. L. (2003). The emergence of Taenia solium cysticercosis in Eastern and Southern Africa as a serious agricultural problem and public health risk. Acta Tropica, 87, 13-23. https://doi.org/10.1016/S0001-706X (03)00051-2

Poore, K. R., \& Fowden, A. L. (2004). Insulin sensitivity in juvenile and adult pigs of low and high birth weight. Diabetologia, 47, 340-348. https://doi.org/10.1007/s00125-003-1305-3

Quesnel, H., Meunier-Salaün, M. C., Hamard, A., Guillemet, R., Etienne, M., Farmer, C., Pére, M. C. (2009). Dietary fiber for pregnant sows: Influence on sow physiology and performance during lactation. Journal of Animal Science, 87, 532-543. https://doi.org/10.2527/jas.2008-1231

Quiniou, N., Dagorn, J., \& Gaudre, D. (2002). Variation of piglet's birth weight and consequences on subsequent performance. Livestock Production Science, 78, 63-70. https://doi.org/10.1016/S0301-6226 (02)00181-1

Raseel, K., Kotresh, P., \& Sunanda, C. (2016). Study of seasonal variations on productive performance of cross bred pigs in high range regions of Wayanad. International Journal of Science and Nature, 7(2), 287-289. 
Rege, J. E. O., Marshall, K., Notenbaert, A., Ojango, J. M. K., \& Okeyo, A. M. (2011). Pro-poor animal improvement and breeding — what can science do? Livestock Science, 136, 15-28. https://doi.org/10.1016/ j.livsci.2010.09.003

Sharma, B. D., Dubey, C. B., \& Singh, S. K. (1990). A comparison study of growth in purebred and crossbred pigs. Indian Journal of Animal Science, 60(4), 492-495.

Tummaruk, P., \& Khatiworavage, C. (2011). Seasonal effect on the litter size at birth in sows differed among parity groups. Proceedings of the $5^{\text {th }}$ Asian Pig Veterinary Society Congress. Pattaya, Thailand.

Tummaruk, P., Tantasuparuk, W., Techakumphu, M., \& Kunavongkrit, A. (2010). Seasonal influences on the litter size at birth of pigs are more pronounced in the gilt than sow litters. Journal of Agricultural Science, 148, 421-432. https://doi.org/10.1017/S0021859610000110

Wysokinska, A., \& Kondracki, S. (2013). Assessment of the effect of heterosis on semen parameters of two-breed crosses of Duroc, Hampshire and Pietrain boars. Archives Animal Breeding, 56, 65-74. https://doi.org/10.7482/0003-9438-56-007

\section{Copyrights}

Copyright for this article is retained by the author(s), with first publication rights granted to the journal.

This is an open-access article distributed under the terms and conditions of the Creative Commons Attribution license (http://creativecommons.org/licenses/by/4.0/). 